Research Article

\title{
Deformation Control Method of the Antislide Pile under Trapezoidal Load in the Zhangjiawan Landslide
}

\author{
Hao Wang $\mathbb{D}^{1},{ }^{1}$ Zhiying Lv, ${ }^{1}$ Hongyu Qin, ${ }^{2}$ Jianwei Yue, ${ }^{1}$ and Jianwei Zhang $\mathbb{D}^{1}$ \\ ${ }^{1}$ School of Civil Engineering and Architecture, Henan University, Kaifeng 475004, Henan, China \\ ${ }^{2}$ College of Science and Engineering, Flinders University, Adelaide 5042, SA, Australia \\ Correspondence should be addressed to Jianwei Zhang; zjw101_0@163.com
}

Received 25 January 2020; Revised 7 June 2020; Accepted 17 June 2020; Published 8 July 2020

Academic Editor: Xuzhen He

Copyright (c) 2020 Hao Wang et al. This is an open access article distributed under the Creative Commons Attribution License, which permits unrestricted use, distribution, and reproduction in any medium, provided the original work is properly cited.

Antislide piles are set in the Zhangjiawan landslide area, where the general features of the bedrock below the slip surface include upper weak and lower hard strata. Based on a site investigation, the horizontal displacement of the antislide pile head is $14.8 \mathrm{~cm}$, which is not conducive to the stability of the landslide. In the study, a displacement calculation method for the pile under trapezoidal load is proposed for a colluvial landslide controlling. Furthermore, factors affecting the deformation and internal forces of the pile were also studied. The results indicated that (1) when the embedded length of an antislide pile increases, the horizontal displacement on the pile and maximum absolute shear force decrease, while the bending moment of the pile exhibits opposite trends; (2) the relationship between maximum shear force and maximum bending moment is linear with increasing driving force of landslide; and (3) increase in the ratio of the driving force between the pile head and slip surface $\left(q 0 / q_{1}\right)$ steadily increases the horizontal displacement of the pile. The relationship between the distribution of the driving force $\left(q 0 / q_{1}\right)$ and the reasonable embedded length of a pile is a quadratic function, which can be used to determine the reasonable embedded length of a pile under the action of rectangular or triangular loads. It is very useful to use the above method to guide the design of antislide piles in similar areas.

\section{Introduction}

Several colluvial landslides have occurred in the northeastern Sichuan province of China. Cretaceous strata constitute the main characteristics in the area and have attracted increasing attention [1]. Cretaceous strata are characterized as weak and hard intercalated rocks. Antislide piles are installed in bedrocks with upper weak rock and lower hard rock to stabilize landslides [2]. The heads of some antislide piles exhibit horizontal displacement. If the deformation of the pile head is excessively high, cracks are formed in the landslide body behind the pile and thus provide a channel for surface water infiltration and increase the risk of landslide [3].

Several recent studies examined the mechanism of pile deformation. The deformation behavior of piles is related to the section shape and slenderness ratio of piles $[4,5]$. Antislide piles were used to control floor heave in the roadway project. The burial depth and deformation of piles are affected by soil stress conditions [6]. The deformation of the pile head decreases with increases in pile diameter and increases with increases in the slope angle [7]. The lateral behavior of two-pile group foundations installed in weathered rock slopes was also severely affected by the angle of the slope [8]. In landslide controlling, antislide piles play an important role and coordinate deformation with the surrounding soil to improve the stability of the whole slope [9-12]. The excavation or increases in the driving force of landslides behind piles lead to the deformation of piles and even pile damage [13-15]. The distributions of slope pressure that act on the section of an antislide pile significantly affect the internal force and deformation on the pile $[16,17]$. The equation of pile deformation, as proposed under different lateral load patterns, is related to the elastic modulus and moment of inertia of the pile. The cantilever pile length affects the distributions of slope pressure above the slip 
surface $[18,19]$. The calculation of pile displacement was achieved under certain loads [20]. Upon increasing the number of piles, the location of the maximum bending moment of the pile shifted to the pile head [21]. With the driving force of the landslide, stratum property, and relative stiffness of the pile remaining unchanged, it was found that the embedded depth of the antislide pile directly affects the internal force and displacement [22].

The effective embedded length of antislide piles to reinforce slopes has been analyzed by numerical simulation and theoretical calculation. Wei and Cheng [23] adopted a strength reduction to examine the reinforcement of row piles on a slope. Liu and Liu [24], Yang et al. [25], and Li et al. [26] investigated the effects of pile spacing and pile head conditions on the critical pile length. The factor of safety increases with decreases in pile spacing. When the embedded length of the pile exceeds the critical value, the slope safety factor does not increase. Li et al. [27] investigated the reason for pile deformation by installing an upper hard and lower weak stratum. The horizontal displacement of the piles decreased with increases in the embedded length of the piles. Zhou et al. [28] focused on the mechanism of pile deformation in variable rock mass properties. The lateral deformation of the pile decreased with increases in bedrock Geological Strength Index (GIS).

The aforementioned studies examined the mechanism of pile deformation with a single rock layer and also focused on the effect of pile length on slope stability with a multilayered stratum. However, the interaction mechanism between the deformation behavior of antislide piles under trapezoidal distributed load in multilayered bedrock with upper weak and lower hard stratum and corresponding approaches to control the deformation are highly important. There is a paucity of research in this area. We used a case study of the Zhangjiawan landslide in Tongjiang county in the northeast Sichuan province, China. The objective of our study is to propose a method for ascertaining the reasonable embedded length of antislide piles to control the deformation of pile head under the different distributions of the driving force $\left(q 0 / q_{1}\right)$ in the area with upper weak and lower hard strata. The factors affecting the reasonably embedded length of antislide piles, pile deformation, and internal forces are also analyzed in detail.

\section{Methodology and Validation}

2.1. Calculation Method for Antislide Pile in Two Different Strength Bedrocks. Antislide pile can be classified into an elastic pile and rigid pile. Based on the Second Surveying and Design Institute of the National Department of Chinese Railways, a pile corresponds to a rigid pile when $\beta \times h<1.0$, and it corresponds to an elastic pile otherwise [29]. Specifically, $h$ denotes the embedded section length of the pile. The pile deformation coefficient $(\beta)$ is calculated as follows:

$$
\beta=\left(\frac{k \cdot B_{\mathrm{p}}}{4 \mathrm{EI}}\right)^{(1 / 4)},
$$

where $k$ denotes subgrade reaction modulus of the bedrock for antislide pile under the action of lateral forces determined by the compressive strength of the rock [29], $E$ denotes Young's modulus of the pile, $I$ denotes the moment of inertia of the pile, and $B_{p}$ denotes the calculation width of the pile $\left(B_{p}=b+1\right.$, for the rectangular section; $b$ denotes the width of the pile section) [29].

In engineering, most of the antislide piles are elastic piles, based on equation (1). For a bedrock composed of two kinds of rock layers (see Figure 1(a)), the lateral load acting on the pile below the slip surface is expressed by two equations, as follows [30]:

$$
\begin{cases}\mathrm{EI} \frac{\mathrm{d}^{4} x}{\mathrm{~d} y^{4}}+x k_{1} B_{P}=0, & \left(0 \leq y \leq y_{1}\right), \\ \mathrm{EI} \frac{\mathrm{d}^{4} x}{\mathrm{~d} y^{4}}+x k_{2} B_{P}=0, & \left(y_{1}<y \leq h\right),\end{cases}
$$

where $k_{1}$ denotes the modulus of the subgrade reaction of the first layer of rock below the slip surface, $y_{1}$ denotes the thickness of the rock; $k_{2}$ denotes the modulus of the subgrade reaction of the second layer of rock below the slip surface, and $h$ denotes the embedded length of the anti-slide piles below the slip surface. The other parameters are identical to those afore-described.

By solving the two equations shown in equation (2), the following expressions are obtained [30]:

$$
\left\{\begin{array}{l}
M_{y i}=-4 x_{i-1} \beta_{i}^{2} \mathrm{EI} \varphi_{3 i}-4 \theta_{i-1} \beta_{i} \mathrm{EI} \varphi_{4 i}+M_{i-1} \varphi_{1 i}+\frac{Q_{i-1}}{\beta_{i}} \varphi_{2 i}, \\
Q_{y i}=-4 x_{i-1} \beta_{i}^{3} \mathrm{EI} \varphi_{2 i}-4_{i-1} \beta_{i}^{2} \mathrm{EI} \varphi_{3 i}-4 M_{i-1} \beta_{i} \varphi_{4 i}+Q_{i-1} \varphi_{1 i}, \\
\theta_{y i}=\beta_{i}\left(-4 x_{i-1} \varphi_{4 i}+\frac{\theta_{i-1}}{\beta_{i}} \varphi_{1 i}+\frac{M_{i-1}}{\beta_{i}^{2} \mathrm{EI}} \varphi_{2 i}+\frac{Q_{i-1}}{\beta_{i}^{3} \mathrm{EI}} \varphi_{3 i}\right), \\
x_{y i}=x_{i-1} \varphi_{1 i}+\frac{\theta_{i-1}}{\beta_{i}} \varphi_{2 i}+\frac{M_{i-1}}{\beta_{i}^{2} \mathrm{EI}} \varphi_{3 i}+\frac{Q_{i-1}}{\beta_{i}^{3} \mathrm{EI}} \varphi_{4 i}, \\
(i=1,2),
\end{array}\right.
$$

where $Q_{y i}, M_{y i}, \theta_{y i}$, and $x_{y i}$ denote the shear force, bending moment, rotation angle, and horizontal displacement for the pile below the slip surface of the two bedrock strengths, which change with depth, respectively; $i=1$ represents the first layer of rock below the slip surface, and $i=2$ represents the second layer of rock below the slip surface. Additionally, $Q_{1}, M_{1}, \theta_{1}$, and $x_{1}$, denote the shear force, bending moment, rotation angle, and horizontal displacement for the pile at the bottom of the first layer of bedrock, respectively, while $Q_{0}, M_{0}, \theta_{0}$, and $x_{0}$ denote the shear force, bending moment, rotation angle, and horizontal displacement for the pile at the slip surface, respectively. Furthermore, $\varphi_{1 i}, \varphi_{2 i}, \varphi_{3 i}$, and $\varphi_{4 i}$ are the influence moduli that are calculated as follows [27]: 


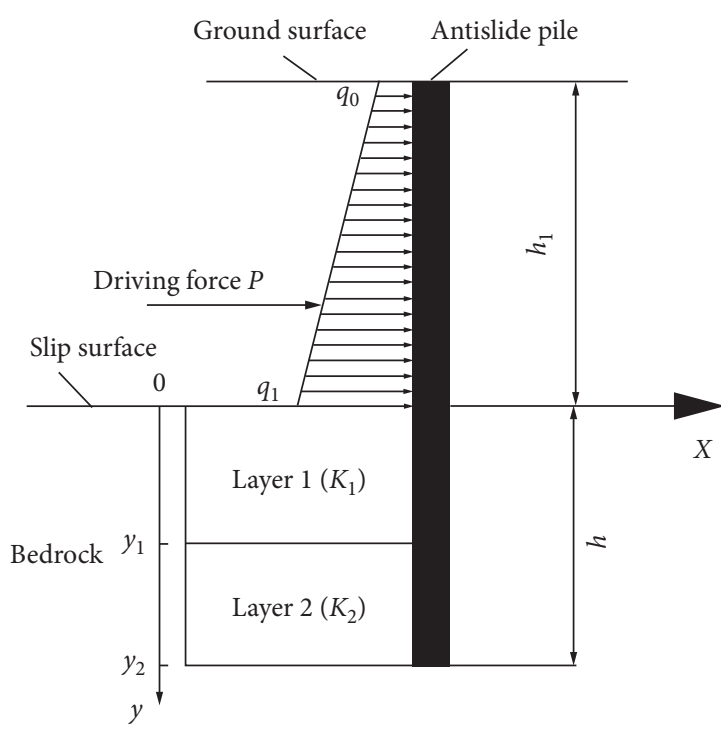

(a)

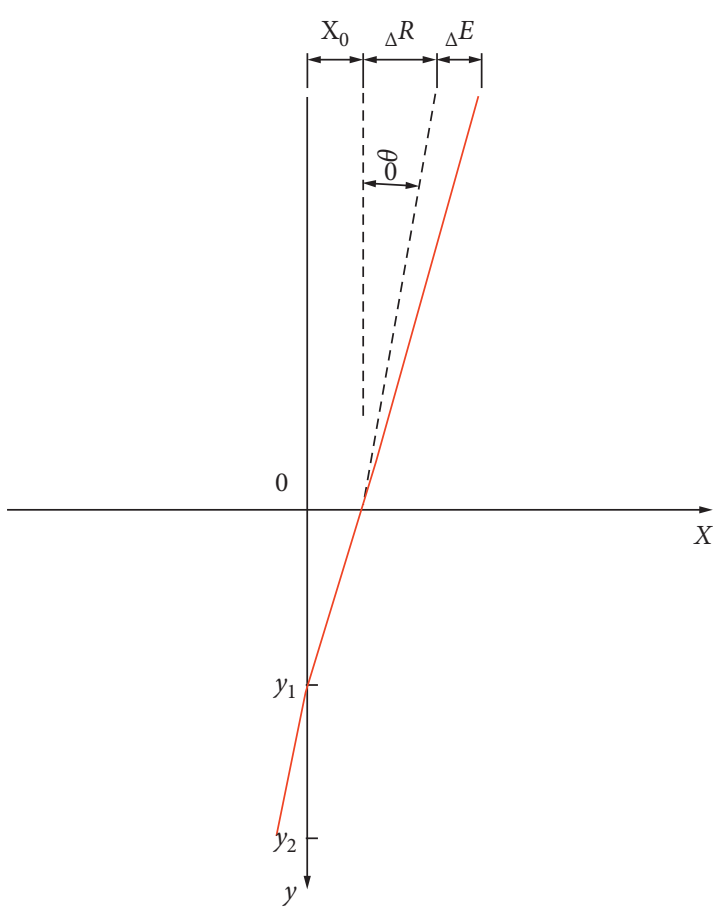

(b)

Figure 1: Stress and deformation model of an antislide pile under a trapezoidal load in two different strength strata. (a) Sketch of the lateral trapezium load acting on a pile. (b) Composition of antislide pile deformation.

$$
\left\{\begin{array}{l}
\varphi_{1 i}=\cos \left(\beta_{i} \cdot \Delta y\right) \cdot \cosh \left(\beta_{i} \cdot \Delta y\right), \\
\varphi_{2 i}=\frac{1}{2}\left[\sin \left(\beta_{i} \cdot \Delta y\right) \cdot \cosh \left(\beta_{i} \cdot \Delta y\right)+\cos \left(\beta_{i} \cdot \Delta y\right) \cdot \sinh \left(\beta_{i} \cdot \Delta y\right)\right], \\
\varphi_{3 i}=\sin \left(\beta_{i} \cdot \Delta y\right) \cdot \sinh \left(\beta_{i} \cdot \Delta y\right), \\
\varphi_{4 i}=\frac{1}{4}\left[\sin \left(\beta_{i} \cdot \Delta y\right) \cdot \cosh \left(\beta_{i} \cdot \Delta y\right)-\cos \left(\beta_{i} \cdot \Delta y\right) \cdot \sinh \left(\beta_{i} \cdot \Delta y\right)\right], \\
\Delta y=y_{i}-y_{i-1}(i=1,2),
\end{array}\right.
$$

where $\Delta y$ denotes the thickness of the rock layer with different strengths below the slip surface, and $y i$ denotes the distance from the origin below the slip surface. Additionally, $\beta i$ is the modulus of deformation, which is obtained by using the following expression [29]. The other parameters are identical to those afore-described:

$$
\beta_{i}=\sqrt[4]{\frac{K_{i} \cdot B_{p}}{\mathrm{EI}}, \quad(i=1,2) .}
$$

In order to simplify the calculation, other external forces of the pile tip are not considered in the calculation. The solution of equation (3) is dependent on $M_{0}, Q_{\underline{0}}, x_{0}$, and $\theta_{0}$. Specifically, $M_{0}$ and $Q_{0}$ can be solved using laterally loaded conditions. Additionally, $x_{0}$ and $\theta_{0}$ are solved by the boundary condition of the pile bottom. There are three types of bottom boundary conditions: free, articulated, and fixed. One of them is selected for the calculation based on specific engineering conditions. By substituting the calculated values of $M_{0}, Q_{0}, x_{0}$, and $\theta_{0}$ into equation (3), the bending moment $\left(M_{y i}\right)$, shear force $\left(Q_{y i}\right)$, horizontal displacement $\left(x_{y i}\right)$, and rotation angle $\left(\theta_{y i}\right)$ are obtained for the load acting on the pile at any depth below the slip surface.

2.2. Calculation Method for Antislide Pile above Slip Surface. To ensure engineering safety, the section of an antislide pile above the slip surface is generally considered as a cantilever beam. Assuming the thrust distribution of the landslide behind the pile is trapezoidal, the shear force $\left(Q_{y}\right)$ and bending moment $\left(M_{y}\right)$ for the pile above the slip surface are expressed as follows based on structural mechanics:

$$
\begin{cases}Q_{y}=q 0\left(h_{1}-|y|\right)+\frac{\left(q_{1}-q 0\right)\left(h_{1}-|y|\right)^{2}}{2 h_{1}}, & \left(y<0,|y| \leq h_{1}\right), \\ M_{y}=\frac{q 0\left(h_{1}-|y|\right)^{2}}{2}+\frac{\left(q_{1}-q 0\right)\left(h_{1}-|y|\right)^{3}}{6 h_{1}}, & \left(y<0,|y| \leq h_{1}\right),\end{cases}
$$

where $y$ denotes the distance from the origin (see Figure $1(\mathrm{a})), h_{1}$ denotes the length of the antislide pile above the slip surface, and $q 0$ and $q_{1}$ denote the distributions of the driving force at the pile head and slip surface, respectively.

The horizontal displacement $\left(\Gamma_{y}\right)$ is related to the pile deformation $\left(X_{0}\right)$, rotation $(\Delta R)$, and displacement $(\Delta E)$ due to the trapezium distributed driving force (see Figure 1(b)). Hence, the displacement of the pile is as follows: 


$$
\Gamma_{y}=X_{0}+\Delta R(y)+\Delta E(y), \quad\left(y<0,|y| \leq h_{1}\right) .
$$

The rotation $(\Delta R)$ is expressed as follows:

$$
\Delta R(y)=\theta_{0} \times|y|, \quad\left(y<0,|y| \leq h_{1}\right) .
$$

As aforementioned, the displacement $(\Delta E)$ of a pile induced by the trapezoidal thrust load of the landslide is calculated as follows:

$$
\begin{aligned}
\Delta E(y)= & \frac{\left(q_{1}-q 0\right)}{120 \mathrm{EI} h_{1}}\left[4 h_{1}^{5}-5 h_{1}^{4}\left(h_{1}-|y|\right)+\left(h_{1}-|y|\right)^{5}\right]+\frac{q 0}{24 \mathrm{EI}} \\
& \cdot\left[3 h_{1}^{4}-4 h_{1}^{3}\left(h_{1}-|y|\right)+\left(h_{1}-|y|\right)^{4}\right], \quad\left(y<0,|y| \leq h_{1}\right) .
\end{aligned}
$$

Subsequently, equations (8) and (9) are introduced into equation (7), and the complete expression for the horizontal displacement of an antislide pile above the slip surface is obtained as follows:

$$
\begin{aligned}
\Gamma_{y}= & X_{0}+\theta_{0} \times y+\frac{\left(q_{1}-q 0\right)}{120 \mathrm{EI} h_{1}}\left[4 h_{1}^{5}-5 h_{1}^{4}\left(h_{1}-|y|\right)+\left(h_{1}-|y|\right)^{5}\right] \\
& +\frac{q 0}{24 \mathrm{EI}}\left[3 h_{1}^{4}-4 h_{1}^{3}\left(h_{1}-|y|\right)+\left(h_{1}-|y|\right)^{4}\right], \quad\left(y<0,|y| \leq h_{1}\right) .
\end{aligned}
$$

2.3. Validation of the Calculation Method for a Pile. Zhou et al. [31] used the finite element model coupled with a shear strength reduction method (FE-SRM) to calculate the internal force of a pile and obtain its distribution (see Figure 1(a)) under the lateral force of a landslide. The crosssection width $(b)$ of the pile is $2.5 \mathrm{~m}$, and the cross-sectional height $(a)$ of the pile is $3 \mathrm{~m}$. The moment of inertia of the antislide pile $(I)$ is $b \times a^{3} / 12=5.63 \mathrm{~m}^{4}$. Young's modulus $(E)$ of the antislide pile is $3.0 \times 10^{7} \mathrm{kPa}$. The driving force acting on the pile is $1549 \mathrm{kN} / \mathrm{m}$. The ratio of the driving force between the pile head and slip surface $\left(q 0 / q_{1}\right)$ is 0.5 . The buried length of the antislide pile is $6.5 \mathrm{~m}(h=6.5 \mathrm{~m})$, and the pile length above the slip surface is $10.5 \mathrm{~m}\left(h_{1}=10.5\right)$. The modulus of the subgrade reaction of the bedrock under slip surface $K$ is $1.0 \times 10^{5} \mathrm{kPa} / \mathrm{m}$. The geotechnical parameters are listed in Table 1.

To validate the method, the same parameters are used to calculate the internal force of the pile. The results are presented in Figure 2.

The calculation of the bending moment of the pile with depth using the proposed method with the pile hinge is consistent with the FE-SRM method. However, when the pile bottom is free, the maximum bending moment is $6.4 \%$ lower than that of the FE-SRM method (see Figure 2(a)). The calculation of the shear force of the pile above the slip surface using the method is consistent with the FE-SRM method (see Figure 2(b)). However, the maximum shear force below the slip surface calculated by our method is slightly less than the FE-SRM method. The slight difference may be caused by the plastic deformation of the bedrock below the slip surface. The pile bottom shear force did not correspond to 0 , and the bending moment was 0 , as obtained by the FE-SRM method, which indicated that the boundary condition of the pile bottom is hinged during Zhou's calculation. When the bottom condition of the pile is hinged, the shear and bending moment trends of the pile by our method were consistent with the FE-SRM method (see Figure 2), thereby indicating that the calculation method proposed in the study is reasonable. The method proposed in the study is relatively simple and is used more widely in engineering.

\section{Case Study of Zhangjiawan Landslide}

3.1. Geological Background of the Zhangjiawan Landslide. The Zhangjiawan landslide occurred in Tongjiang County in northeastern Sichuan province, China. The coordinates of the landslide location are $31^{\circ} 54^{\prime} 01^{\prime \prime} \mathrm{N}$ latitude and $107^{\circ} 15^{\prime} 36^{\prime \prime} E$ longitude. The Tongjiang-Pingchang highway (Tongping Road) passes through the front of the landslide. Furthermore, 600 villagers lived in the landslide area. Additionally, No. 2 Middle School of Tongjiang County was threatened by the landslide (see Figure 3).

The Zhangjiawan landslide is approximately $390 \mathrm{~m}$ long and $320 \mathrm{~m}$ wide, and the average thickness of the sliding body is $12 \mathrm{~m}$. The landslide area is approximately $14.43 \mathrm{~km}^{2}$, and the volume is 1.08 million $\mathrm{m}^{3}$ (see Figure $4(\mathrm{a})$ ). The main sliding direction of the sliding body is $292^{\circ}$ (see Figure 4(b)). The Zhangjiawan landslide is a colluvial landslide. Slide body material is dated from the Quaternary through site investigation. The bedrock under the slip surface is the Cangxi Formation with lower Cretaceous strata, composing of sandstone and mudstone interbeds. The tendency of sandstone and mudstone is $248^{\circ}$, and the dip angle is $13^{\circ}$.

3.2. Landslide Stabilizing Measures. Sixteen antislide piles were used to prevent and control the Zhangjiawan landslide, which is located on the outside of Tongping Highway with an elevation of approximately $425 \mathrm{~m}$ (see Figure 4(b)). There are two types of antislide piles with a length of $19 \mathrm{~m}$ (A-type) and $14 \mathrm{~m}$ (B-type), respectively. The A-type and B-type piles differ only in length, their cross-sectional width (b) is $2 \mathrm{~m}$, and their cross-sectional height (a) is $3 \mathrm{~m}$. The spacing between these antislide piles is $6 \mathrm{~m}$. There are six A-type piles with an embedded section length $(h)$ of $7 \mathrm{~m}$ and pile length above the slip surface $\left(h_{1}\right)$ of $12 \mathrm{~m}$. There are ten B-type piles with a length of $(H) 14 \mathrm{~m}$. Located at the position of the antislide pile, the bedrock is composed of an upper mudstone (weak) layer approximately $1 \mathrm{~m}$ deep and a lower sandstone (hard) layer that is approximately $6 \mathrm{~m}$ deep. The sliding mass is composed of soil intercalated with gravel, and thus the distribution pattern of the driving force behind a pile corresponds to a trapezium [29]. The value is represented by $q 0 / q_{1}$. Some of the pile bottoms are located in the weak rock layer due to the interbedding relationship between sandstone and mudstone, and thus free conditions can be considered at the pile tip. 
TABLe 1: Calculation parameters of geotechnical materials for the landslide.

\begin{tabular}{|c|c|c|c|c|c|c|}
\hline $\begin{array}{l}\text { Geotechnical } \\
\text { classification }\end{array}$ & $\begin{array}{c}\text { Saturated density } r_{\text {sat }} \\
\left(\mathrm{g} / \mathrm{cm}^{3}\right)\end{array}$ & $\begin{array}{c}\text { Density } r \\
\left(\mathrm{~g} / \mathrm{cm}^{3}\right)\end{array}$ & $\begin{array}{c}\text { Cohesion } C \\
(\mathrm{kPa})\end{array}$ & $\begin{array}{c}\text { Internal friction } \\
\text { angle } \Phi\left(^{\circ}\right)\end{array}$ & $\begin{array}{c}\text { Young's modulus } E \\
\left(\mathrm{kN} / \mathrm{m}^{2}\right)\end{array}$ & $\begin{array}{l}\text { Poisson's } \\
\text { ratio }\end{array}$ \\
\hline Soil & 2.24 & 2.2 & 32.7 & 15.6 & 30 & 0.3 \\
\hline $\begin{array}{l}\text { Bedrock (siltsone and } \\
\text { mudstone) }\end{array}$ & 2.53 & 2.5 & 300 & 33 & $1.1 \times 10^{3}$ & 0.25 \\
\hline
\end{tabular}

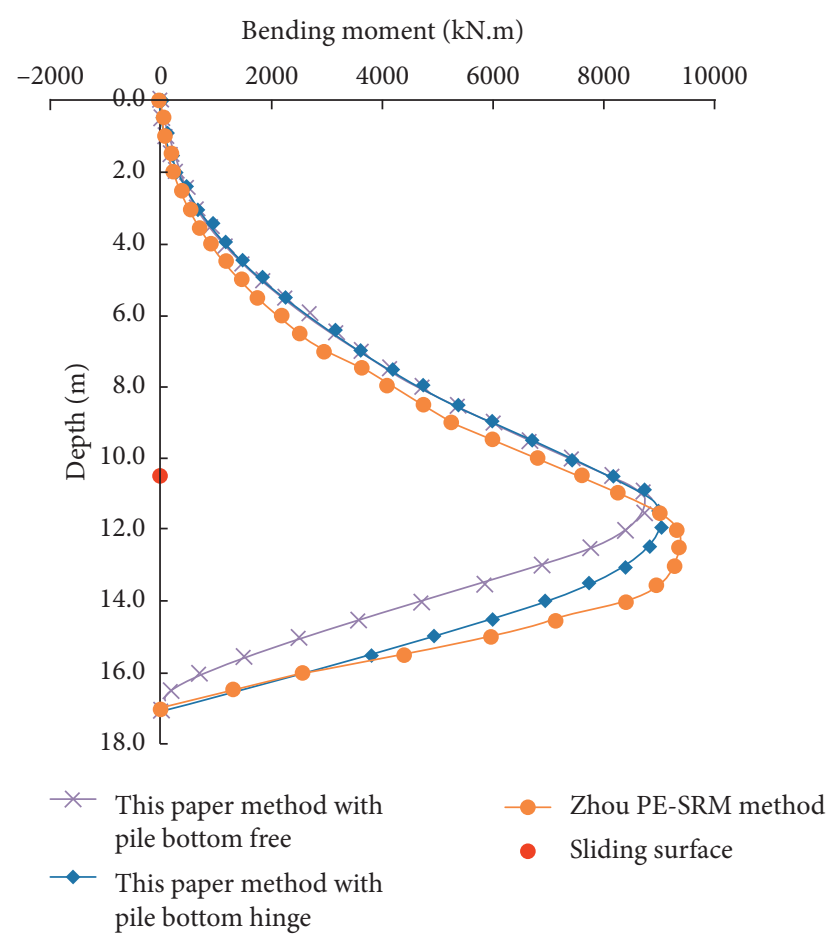

(a)

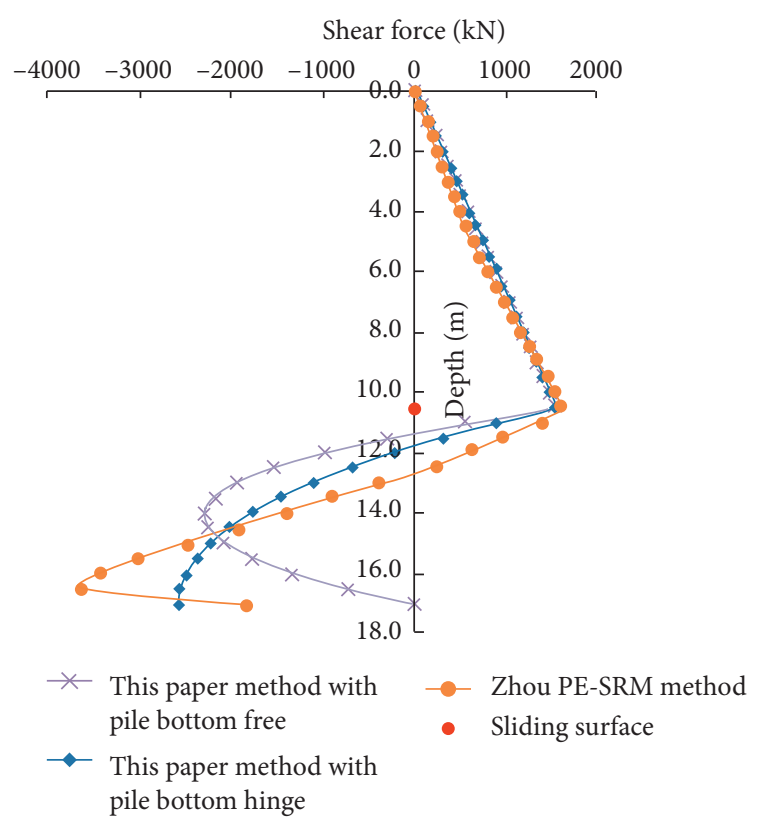

(b)

Figure 2: Calculated values of internal forces of the pile using various methods. (a) Shear force. (b) Bending moment.

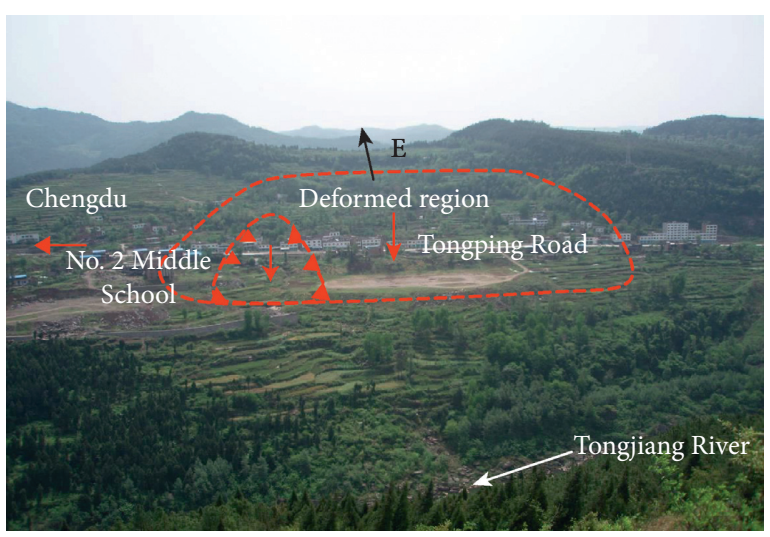

FIgUre 3: Plane view of Zhangjiawan landslide.

3.3. Site Investigation of Antislide Pile Deformations. Electronic total station displacement monitoring (see Figure 5(a)) and site investigation were conducted to further examine the deformation behavior of antislide piles. Several evident cracks were discovered at the back edges of the antislide piles during the site investigation of the Zhangjiawan landslide. The widest crack is approximately $14.8 \mathrm{~cm}$ (see Figure 5(b)) as indicated by site measurement, which is consistent with the monitoring results of the pile head by the total electronic station. The cracks in the landslide body would provide a channel for surface water seeping into the ground. Water weakens the strength of mudstone below the slip surface and increases the risk of landslide [3]. Hence, the causes of the deformation of the antislide pile should be further examined to guide the design of antislide piles in a similar bedrock area.

3.4. Laboratory Test. A site investigation area (see Figure 5(b)) is located at the rear edge of the Zhangjiawan landslide with a steep cliff in the Cangxi Formation of the Lower Cretaceous $\left(K_{\mathrm{lc}}\right)$. In order to further examine the physical and mechanical parameters of the bedrock, some rock samples were collected for laboratory tests (see Figure 6). The experimental results of the geotechnical parameters are shown in Table 2. In the site investigation 

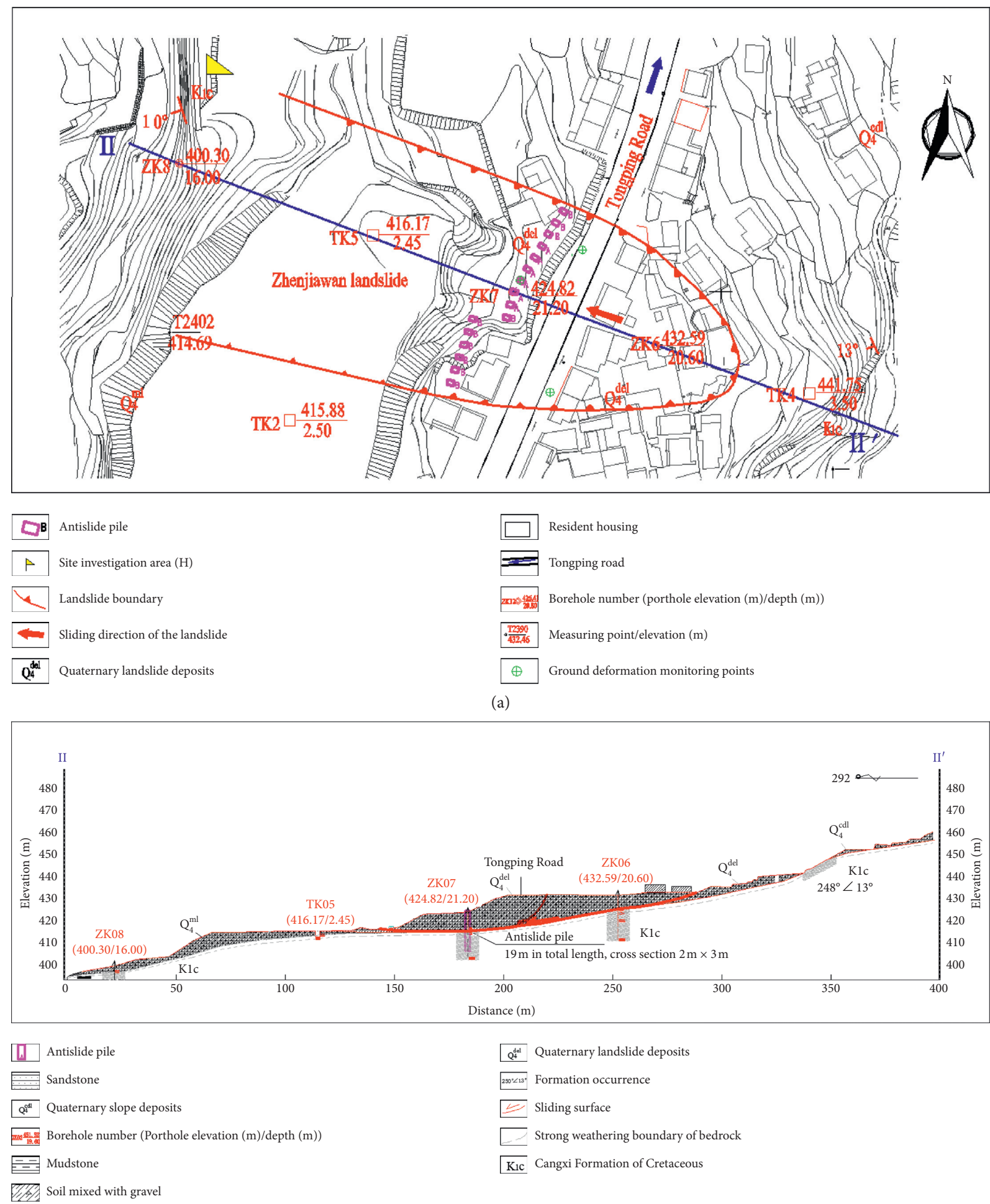

(b)

Figure 4: Engineering geology conditions of Zhangjiawan landslide. (a) Geological map of the Zhangjiawan landslide. (b) Cross-section from II to II' $^{\prime}$ of the Zhangjiawan landslide.

region, the characteristics of the rock are similar to those of the bedrock of the Zhangjiawan landslide.

Laboratory compressive strength tests were conducted to determine the modulus of the subgrade reaction of the bedrock [32]. The compressive strength test device system was developed by the rock test code of highway engineering based on industrial standards [33]. The results of the laboratory compressive test indicated that the compressive strengths of the moderately weathered mudstone and weathered sandstone are $6.4 \mathrm{MPa}$ and $29.74 \mathrm{MPa}$, 


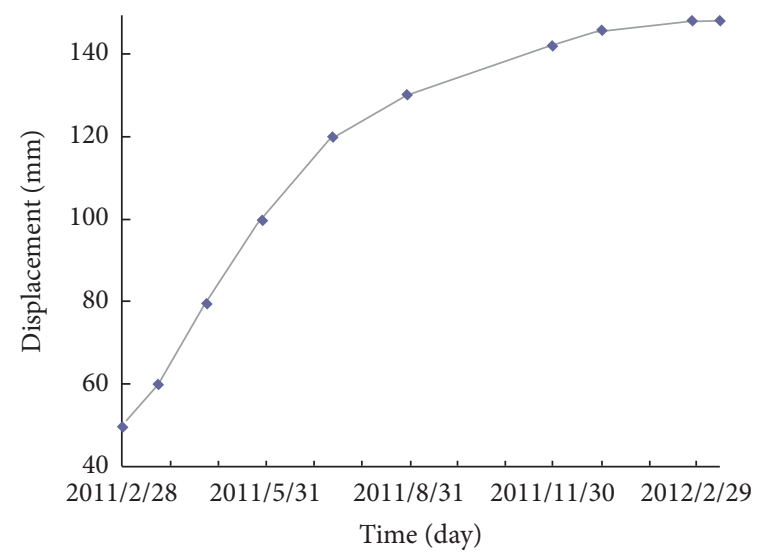

(a)

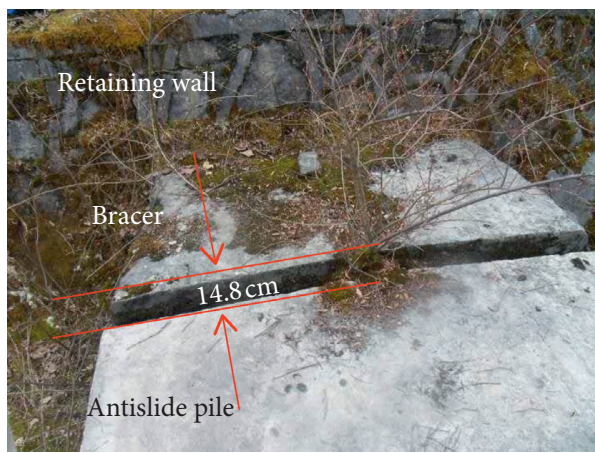

(b)

FiguRe 5: Site investigation of antislide pile deformations. (a) The maximum displacement of the pile head by Lycra automatic total station. (b) Displacement of the antislide pile head in the site investigation.

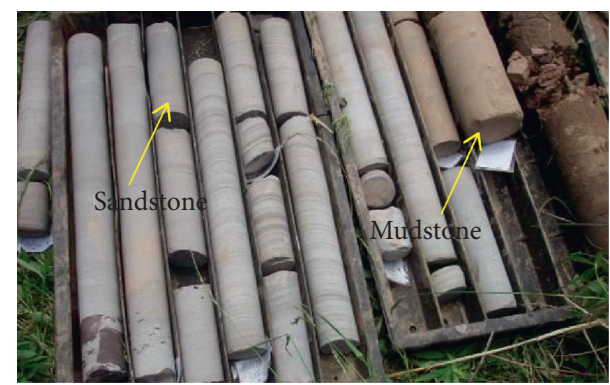

FIgURE 6: Core samples of mudstone and sandstone in site investigation area $(H)$.

respectively. The corresponding moduli of the subgrade reaction of the moderately weathered mudstone and sandstone are $1 \times 10^{5} \mathrm{kN} / \mathrm{m}^{3}$ and $3 \times 10^{5} \mathrm{kN} / \mathrm{m}^{3}$, respectively, based on industrial standards [29].

\section{Study of the Influence of Antislide Pile Deformation and Internal Force}

4.1. Effect of Embedded Length on Pile Deformation and Internal Force. The antislide pile (A-type) at a section from II to II' of the Zhangjiawan landslide (see Figure 4(b)) was selected for the calculation. The moment of inertia of the antislide pile $(I)$ is $b \times a^{3} / 12=4.5 \mathrm{~m}^{4}$. Young's modulus $(E)$ of the antislide pile is $3.0 \times 10^{7} \mathrm{kPa}$. The driving force of the landslide $(p)$ is $1400 \mathrm{kN} / \mathrm{m}$. The ratio of the driving force between the pile head and slip surface $\left(q 0 / q_{1}\right)$ is 0.4 . The thickness of the upper layer of mudstone is $1 \mathrm{~m}\left(y_{1}=1\right)$, and the lower layer of sandstone is $6 \mathrm{~m}$ thick. Therefore, the embedded length of the antislide pile below the slip surface is $7 \mathrm{~m}(h=7 \mathrm{~m})$, and the pile length above the slip surface is $12 \mathrm{~m}\left(h_{1}=12\right)$. The modulus of the subgrade reaction of the mudstone (the first rock) under slip surface $K_{1}$ is $1.0 \times 10^{5} \mathrm{kPa} / \mathrm{m}$, and the modulus of the subgrade reaction of the sandstone ((the second rock) under slip surface $K_{2}$ is $3.0 \times 10^{5} \mathrm{kPa} / \mathrm{m}$. Mudstone and sandstone near the slip surface are affected by landslide sliding, which should be considered as weathering conditions. A reduction factor should be considered $(g=0.5)$ for the modulus of the subgrade reaction [27]. Therefore, the modulus of the subgrade reaction of the mudstone is $K_{1 g}=g \times K_{1}=0.5 \times 10^{5} \mathrm{kPa} / \mathrm{m}$, and the modulus of the subgrade reaction for the sandstone is $K_{2 g}=g \times K_{2}=1.5 \times 10^{5} \mathrm{kPa} / \mathrm{m}$. Other parameters of the antislide pile are stated as aforementioned.

The aforementioned parameters are substituted into equation (10), and the displacement of the pile head is $15 \mathrm{~cm}$, which is consistent with the result of the site investigation (approximately $14.8 \mathrm{~cm}$ ). However, this is disadvantageous to the stability of the landslide. It is necessary to examine the effect of the embedded length of the antislide pile on pile deformation and determine the reasonably embedded length. The embedded ratio for the antislide pile should range from $1 / 3$ to $1 / 2$, which is recommended based on industrial standards [34]. Hence, in order to investigate the effect of the embedded length on the deformation of the pile, embedded pile lengths $(h)$ of $7,8,9,10$, and $11 \mathrm{~m}$ are considered, while other conditions did not change. The displacement and internal forces of piles varying with depth are obtained (see Figure 7).

The maximum internal force of the pile is one of the decisive parameters affecting the failure of the antislide pile. In order to study the changes of maximum bending moment and shear force, a sliding depth ratio $\left(R_{L}\right)$ [35] is defined as pile length above the slip surface $\left(h_{1}\right)$ divided by pile length $\left(L, L=h_{1}+h\right)$. When the depth of the buried pile length below the slip surface is $h=7 \mathrm{~m}$, the pile length $L=19 \mathrm{~m}$, then $R_{\mathrm{L}}=0.63$, according to Figure 7 , the maximum bending moment $M_{\max }=49983 \mathrm{kN} \mathrm{m}$ and the maximum shear value $Q_{\max }=13302 \mathrm{kN}$. In the same way, we can establish the relationship between the sliding depth ratio $\left(R_{L}\right)$ and the maximum internal force with the buried pile length changes, as shown in Figure 8.

\subsection{Driving Force behind a Pile: Effect on Pile Deformation and} Internal Force. The driving force of the landslide behind the pile will change with the sliding speed of the landslide. In order to study the influence of the change of driving force on 
TABLE 2: Experimental parameters of geotechnical materials in the survey area.

\begin{tabular}{lccccc}
\hline $\begin{array}{l}\text { Geotechnical } \\
\text { classification }\end{array}$ & $\begin{array}{c}\text { Density } r \\
\left(\mathrm{~g} / \mathrm{cm}^{3}\right)\end{array}$ & Poisson's ratio & $\begin{array}{c}\text { Deformation } \\
\text { modulus }\left(10^{4} \mathrm{MPa}\right)\end{array}$ & $\begin{array}{c}\text { Natural compressive } \\
\text { strength }(\mathrm{MPa})\end{array}$ & $\begin{array}{c}\text { Saturated compressive } \\
\text { strength }(\mathrm{MPa})\end{array}$ \\
\hline $\begin{array}{l}\text { Mudstone } \\
\text { Sandstone }\end{array}$ & 2.49 & 0.17 & 1.2 & 6.4 & 2.2 \\
\end{tabular}

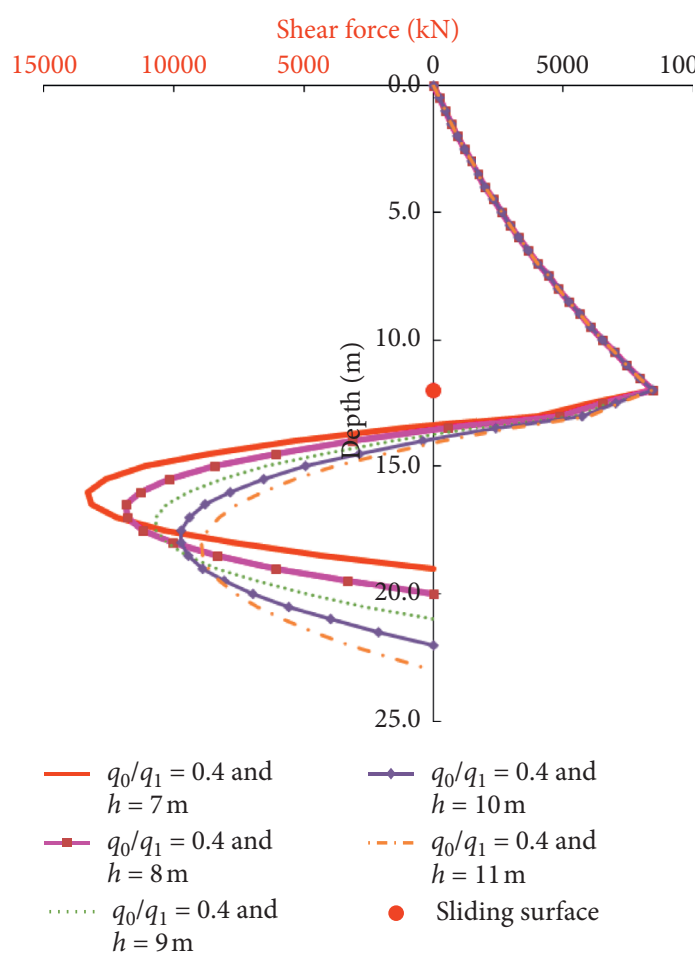

(a)

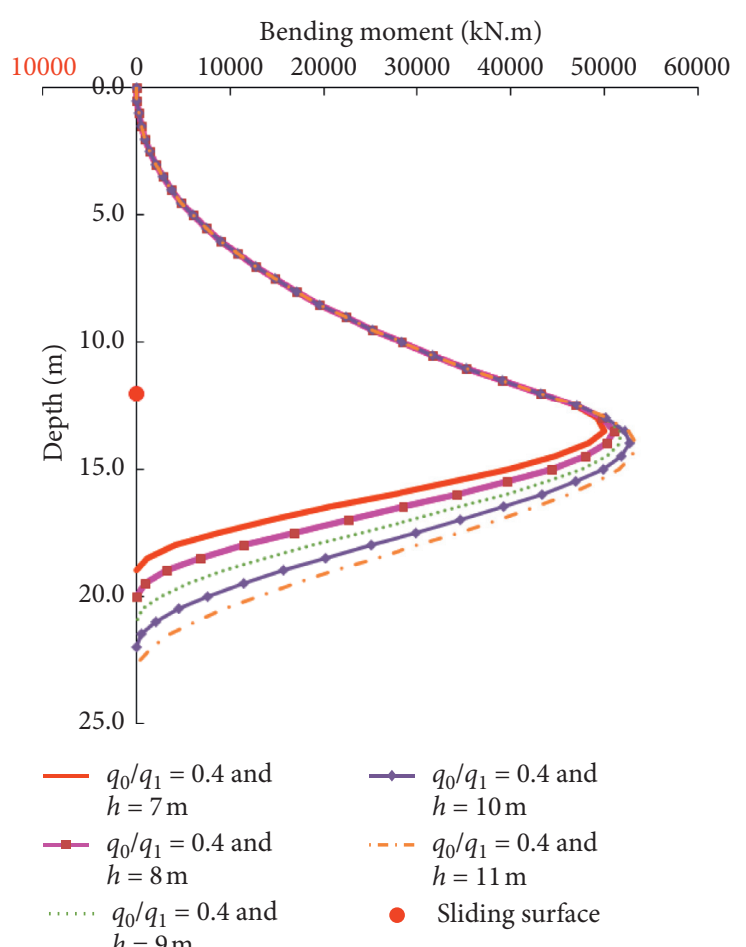

(b)

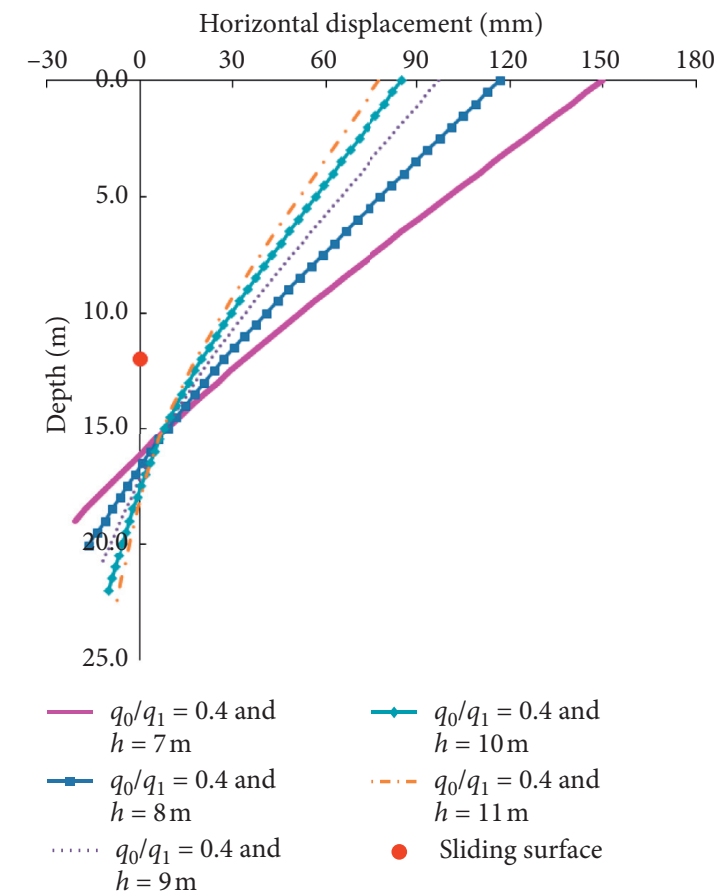

(c)

Figure 7: Calculation results of the displacement and internal forces of the pile under different embedded lengths $h$ with $q 0 / q_{1}=0$. (a) Shear force. (b) Bending moment. (c) Horizontal displacement. 


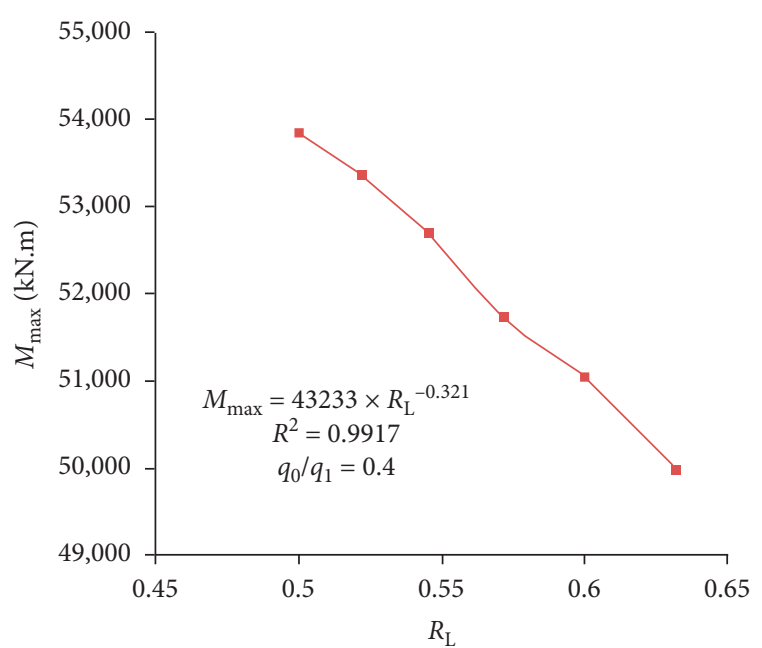

(a)

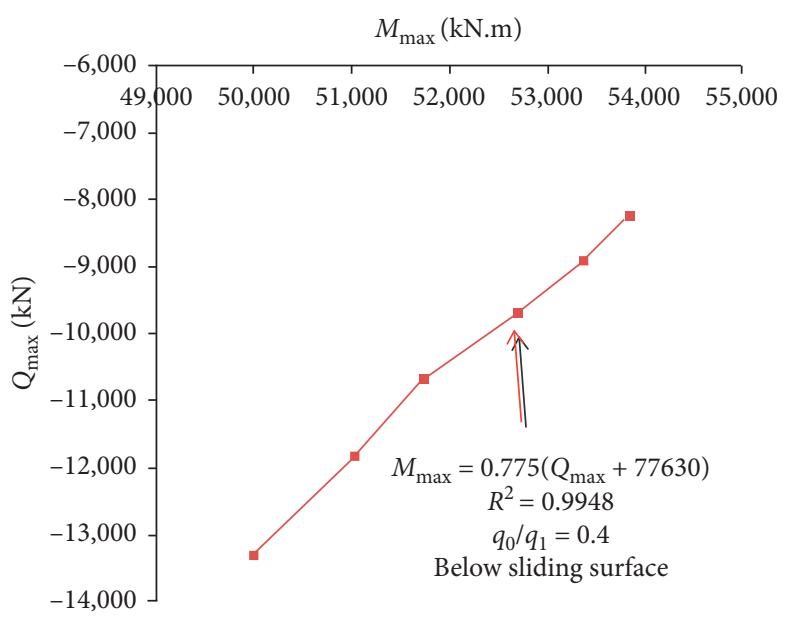

(b)

FIGURE 8: Calculation results of the sliding depth ratio and internal forces of the pile under different embedded lengths. (a) The relationship between the sliding depth ratio and the maximum bending moment. (b) The maximum bending moment and the maximum shear forces below the slip surface of the pile with $P=1400 \mathrm{kN} / \mathrm{m}$.

the internal force of the pile, the driving forces $(P)$ of 300 , $600,900,1200$, and $1500 \mathrm{kN} / \mathrm{m}$ are considered, while other conditions were the same as the antislide pile (A-type) of Zhangjiawan landslide. The displacement and internal forces of piles with the different driving forces are obtained (see Figure 9).

The increase of driving force from 1200 to $1500 \mathrm{kN} / \mathrm{m}$ increases the displacement of the pile head from $128 \mathrm{~mm}$ to $160 \mathrm{~mm}$, which corresponds to an increase of 25\% (see Figure $9(\mathrm{c})$ ). The maximum shear force decreased from $-11402 \mathrm{kN}$ to $-14252 \mathrm{kN}$, and this represents a decrease of $25 \%$ (see Figure 9(a)). The bending moment increased from $42842 \mathrm{kN} \cdot \mathrm{m}$ to $53553 \mathrm{kN} \cdot \mathrm{m}$, which represents an increase of 25\% (see Figure 9(b)).In order to study the change of the maximum internal force of the pile with the different driving force of the landslide, according to the calculation results in Figure 9, the relationship between the maximum bending moment and the maximum shear forces above or below the slip surface was fitted, as shown in Figure 10.

The maximum bending moment increases with the increase of the maximum shear force above the slip surface (see Figure 10), while the maximum bending moment decreases with the increase of the maximum shear force below the slip surface.

4.3. Distribution Pattern of the Driving Force Affects the Pile Deformation. The distribution pattern of the driving force of the landslide behind a pile affects the deformation of the pile [16]. Based on the ratio of the driving force between the pile head and slip surface $\left(q 0 / q_{1}\right)$, the distribution pattern of the driving force is divided into rectangular, triangular, and trapezium. When $q 0 / q_{1}$ is 0 , the distribution pattern of the driving force behind the pile is triangular. When $q 0 / q_{1}$ is 1 , the distribution pattern of the driving force behind the landslides is rectangular. When $q 0 / q_{1}$ is between 0 and 1 , the distribution pattern of the driving force behind the landslides is trapezium [29]. To compare the results obtained with different ratios of driving force between the pile head and slip surface $\left(q 0 / q_{1}\right)$, which were set to 0 and 1, respectively. Variable parameters including the thickness of the lower hard bedrock $\left(\Delta y_{2}\right)$ is $6,7,8,9$, and $10 \mathrm{~m}$, and the corresponding embedded length of a pile $(h)$ is $7,8,9,10$, and $11 \mathrm{~m}$, respectively. The basic parameters of the pile in the calculation are identical to those of the A-type pile in the Zhangjiawan landslide. The results of the horizontal displacement of the pile with various embedded lengths under the action of different values of $q 0 / q_{1}$ are shown in Figure 11 .

When the value of $q 0 / q_{1}$ is 0.4 , the horizontal displacement of the pile with various embedded lengths is shown in Figure 7(c). According to Figures 7(c), 11(a) and 11(b), pile displacement decreases with increases in embedded length, although it exhibits a nonlinear relationship. To better describe the phenomenon, the embedded ratio $(e)$ [30] of an antislide pile is defined as pile length below the slip surface $(h)$ divided by pile length $\left(L, L=h_{1}+h\right)$. When the buried length $(h)$ of the antislide pile is $7 \mathrm{~m}$ under the slip surface, the pile length above the slip surface $\left(h_{1}\right)$ is $12 \mathrm{~m}$ for the Zhangjiawan landslide, and thus the current embedded ratio of the antislide pile is 0.368 . The corresponding displacement of the pile head is $150 \mathrm{~mm}$ (see Figure 7(c)). According to the principle of equivalence $\left(E^{*} \mathrm{I}=E^{*} 0.01625^{*} \pi^{*} D_{\mathrm{eq}}^{4}\right)$ [36], the rectangular shape is equivalent to a round pile with an equivalent diameter $\left(D_{\text {eq }}\right)$ of $3.095 \mathrm{~m}$. Therefore, the current dimensionless displacement of the pile head $\left(\Gamma / D_{\text {eq }}\right)$ is 0.0485 . Hence, the embedded ratio of the other piles can be calculated, and the corresponding dimensionless displacement of the pile head is determined as different distribution of the driving force ( $q 0 /$ $\left.q_{1}\right)$. The interrelation curve between the dimensionless displacement of the pile head and the embedded ratio of the piles is shown in Figure 12. The interrelation equation 


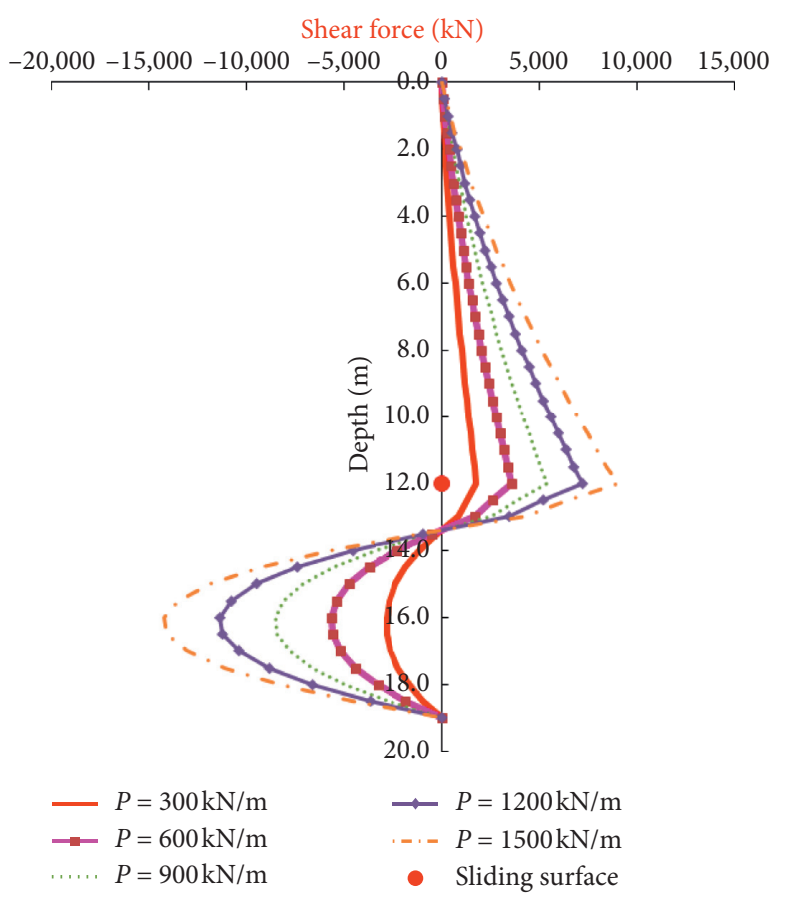

(a)

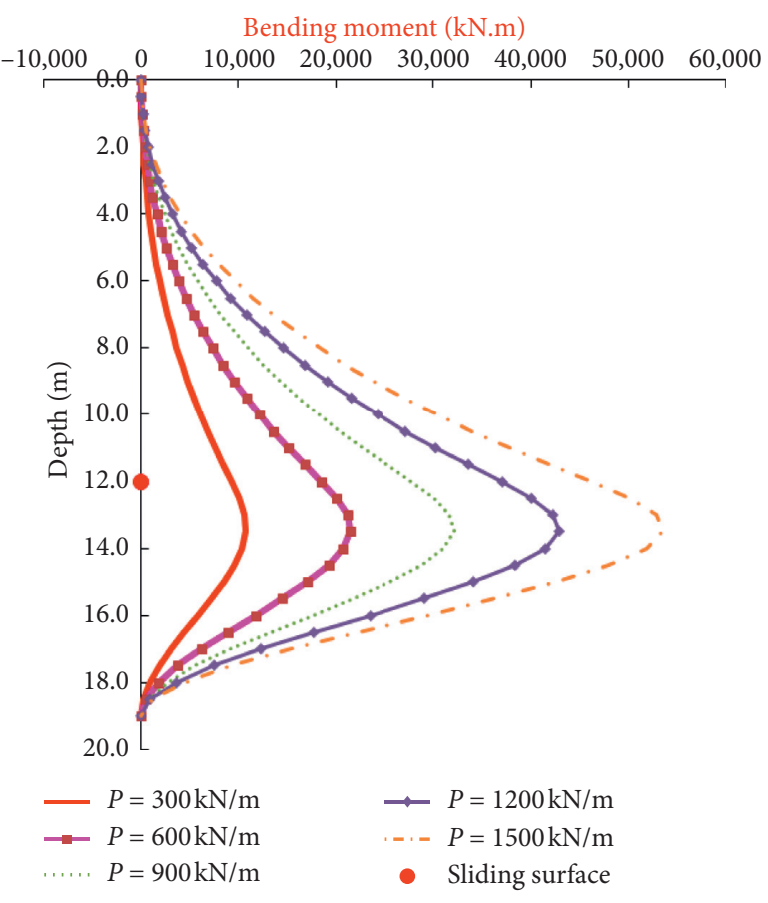

(b)

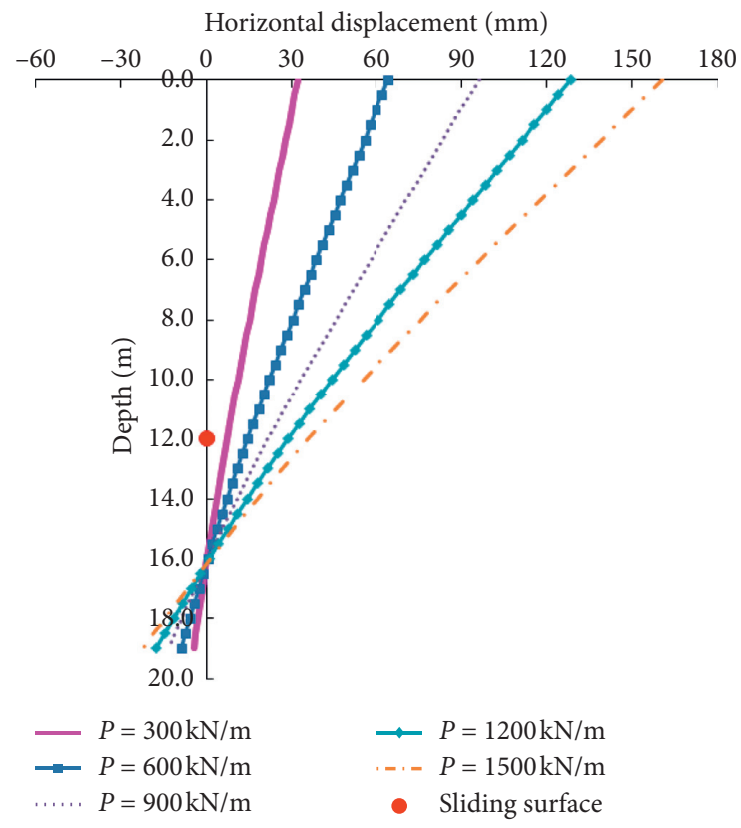

(c)

Figure 9: Calculation results of the displacement and internal forces of the pile under the different driving forces of the landslide. (a) Shear force. (b) Bending moment. (c) Horizontal displacement.

between the embedded ratio $(\varepsilon)$ of the pile and dimensionless displacement of the pile head $\left(\Gamma / D_{\text {eq }}\right)$ is fitted as follows and satisfies a negative power regression.

Based on industrial standards [34], the displacement of the pile head $(\Gamma)$ should be less than $10 \mathrm{~cm}$ and should not exceed $1 / 100$ of the pile length above the slip surface $\left(h_{1}\right)$. When the maximum displacement of the pile head $(\Gamma)$ was $10 \mathrm{~cm}$, the reasonable embedded $(h)$ can be calculated based on the interrelation curve (see Figure 12) as the values of $q 0 /$ $q_{1}$ are $0,0.4$, and 1 . Subsequently, the interrelation equation between the ratio of the driving force between the pile head and slip surface $\left(q 0 / q_{1}\right)$ and reasonably embedded length $(h)$ is fitted as follows:

$$
\frac{h}{D_{\text {eq }}}=-0.0081 \times\left(\frac{q 0}{q_{1}}\right)^{2}+0.576 \times\left(\frac{q 0}{q_{1}}\right)+2.688 .
$$




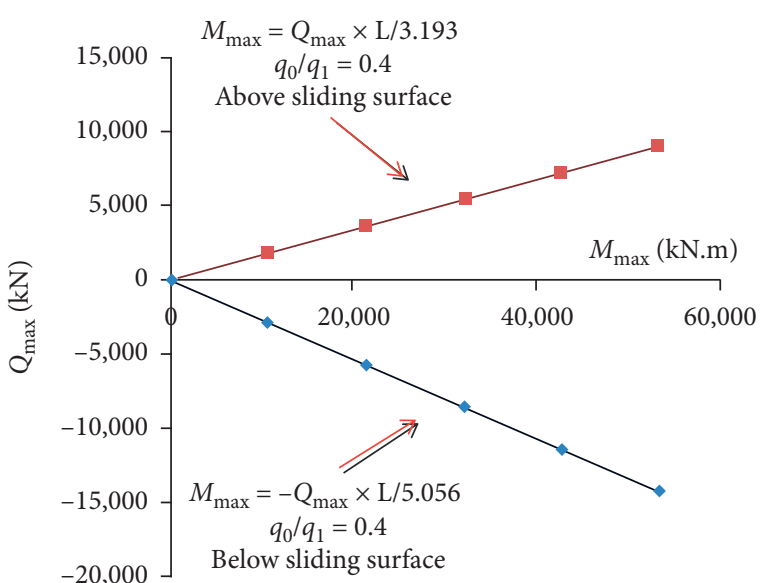

FIgURE 10: Calculation results of the maximum bending moment and the maximum shear forces above or below the slip surface of the pile under different driving forces.

Some parameters of the antislide pile for the Zhangjiawan landslide are stated above, and the ratio of the driving force between the pile head and slip surface $\left(q 0 / q_{1}\right)$ should be 0.4 . By substituting $q 0 / q_{1}=0.4$ into equation (11), the corresponding reasonably embedded length $(h)$ of the pile is $9.03 \mathrm{~m}$. The relationship between the ratio of the driving force between the pile head and slip surface $\left(q 0 / q_{1}\right)$ and reasonably embedded length is not linear. If there are some factors that can increase the value $\left(q 0 / q_{1}\right)$, then it is necessary to consider adding the reasonably embedded length of the pile in practice.

\section{Discussion}

5.1. Thickness of the Lower Bedrock Influenced the Deformation and Internal Forces of the Pile. Pile deformation is as important as internal forces in the piles $[19,37]$, which must be considered for controlling a landslide. Various thicknesses of the lower bedrock below the slip surface significantly affect the deformation and internal forces of the pile. The increase in the thickness of the lower bedrock from $6 \mathrm{~m}$ to $8 \mathrm{~m}$ decreases the displacement of the pile head from $150 \mathrm{~mm}$ to $97 \mathrm{~mm}$, which corresponds to a decrease of $35 \%$ (see Figure 7(c)). The maximum shear force decreased from $13302 \mathrm{kN}$ to $10654 \mathrm{kN}$, and this represents a decrease of $20 \%$ (see Figure $7(\mathrm{a})$ ). The bending moment increased from $49983 \mathrm{kN} \cdot \mathrm{m}$ to $51736 \mathrm{kN} \mathrm{m}$, which represents an increase of $3.5 \%$ (see Figure 7(b)).

The aforementioned comparisons show that simultaneous increases in the thickness of the lower bedrock and the embedded length of an antislide pile decrease horizontal displacement on the pile and its maximum absolute shear force although the bending moment of the pile exhibits opposite trends. An increase in the pile length causes the change in the force arm leading to an increase in the bending moment of the pile. The excessive bending moment increases the amount of bending reinforcement and the cost of the design of an antislide pile. Therefore, the buried depth of the pile should not be excessively long.
When the driving force of the landslide is unchanged, the maximum bending moment decreases as the sliding depth ratio increases (see Figure 8(a)). But the rate is greater than the results of Guo and Qin [35] and Poulos [38], mainly because the calculation condition in this paper is that the pile deforms in the rock, while the research condition of Poulos and Guo is that the pile deforms in the soil. When the driving force of the landslide is constant, the maximum bending moment increases with the increase of the maximum shear force below the slip surface, which is opposite to the change of driving force (see Figure 8(b) and Figure 10).

5.2. Driving Force of the Landslide Influenced the Deformation of the Pile. As the driving force of the landslide increases, the internal force and deformation of the pile increase (see Figure 9). In the process of increasing the driving force of landslide, the relationship between maximum shear force and maximum bending moment is linear (see Figure 10). Where the slope of the linear relationship above the slip surface is less than the slope of the linear relationship below the slip surface, it is different from Qin and Guo [39] and Poulos's research [40], and their slope of the linear relationship is almost the same. This is mainly due to the different pile length ratios above the slip surface and below the slip surface in our research.

The ratio of driving force between the pile head and slip surface $\left(q 0 / q_{1}\right)$ and is an important factor in the design $[16,18]$. The ratio of the driving force between the pile head and slip surface $\left(q 0 / q_{1}\right)$ significantly affects the deformation behavior of the piles. As shown in Figure 11, when the ratio of the driving force between the pile head and slip surface $\left(q 0 / q_{1}\right)$ increases from 0 to 1 with an embedded length of $7 \mathrm{~m}$, the displacement of the pile top increases from $128 \mathrm{~mm}$ to $166 \mathrm{~mm}$, which represents an increase of $30 \%$. When the embedded length of the pile increases from 7 to 11 with the ratio of the driving force between the pile head and slip surface $\left(q 0 / q_{1}\right)$ of 1 , the displacement of the pile top increases from $166 \mathrm{~mm}$ to $86 \mathrm{~mm}$, which represents a decrease of $48.2 \%$ (see Figure 11(b)). The increase in the value of $q 0 / q_{1}$ steadily increases the displacement of the pile. Li et al. [27] use $q 0 / q_{1}=1$ for landslide antislide piles design, which calculates the maximum deformation of the pile under the fixed driving force of a landslide.

When the value of $q 0 / q_{1}$ increases, the embedded rate should increase to keep the same dimensionless displacement of the pile head (see Figure 12). The relationship between the ratio of the driving force between the pile head and slip surface $\left(q 0 / q_{1}\right)$ and the reasonably embedded length of a pile is a quadratic function. Li et al. [27] thought that the relationship between the values of the driving force and the reasonably embedded length of a pile is a linear equation. Therefore, the reasonably embedded length for antislide piles can be used to control the horizontal displacement of the pile head under different distributions $\left(q 0 / q_{1}\right)$ or under different driving forces of the landslide.

Additionally, other factors can also potentially affect the pile deformation and internal force, such as a cross-section 


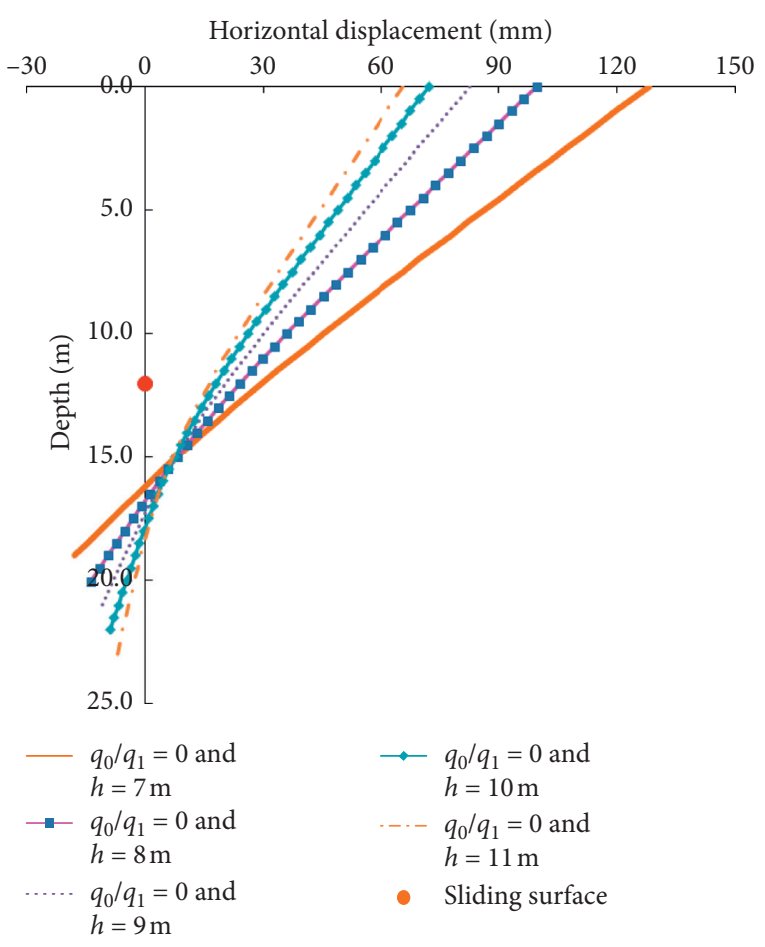

(a)

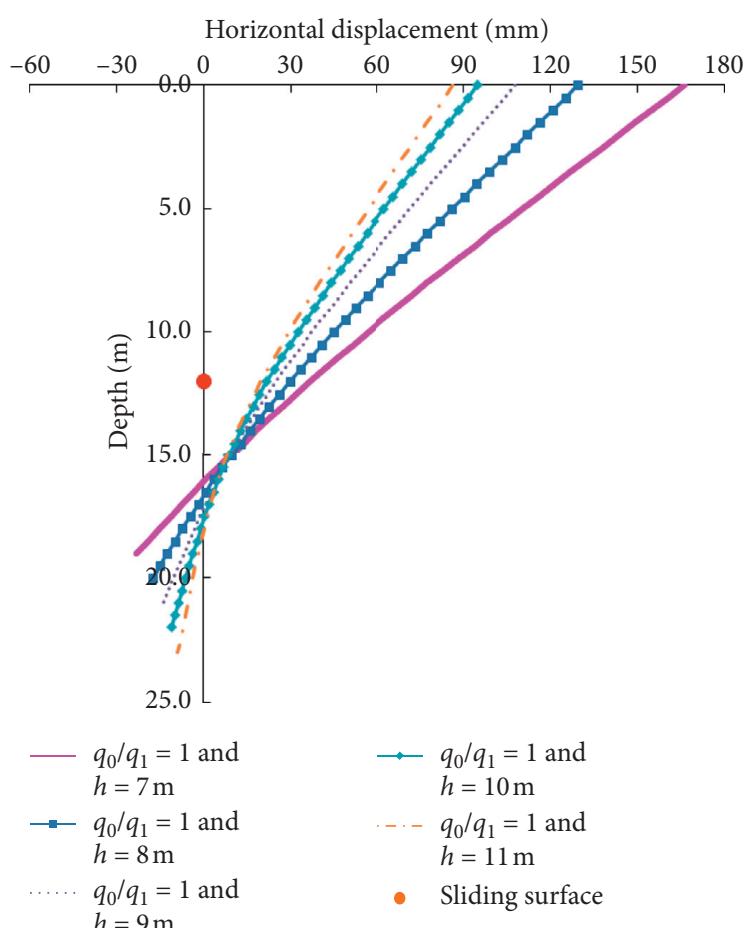

(b)

FIGURE 11: Calculated values of horizontal displacement for piles of various embedded lengths with different values of $q 0 / q_{1}$. (a) Horizontal displacement under $q 0 / q_{1}=0$.(b) Horizontal displacement under $q 0 / q 1=1$.

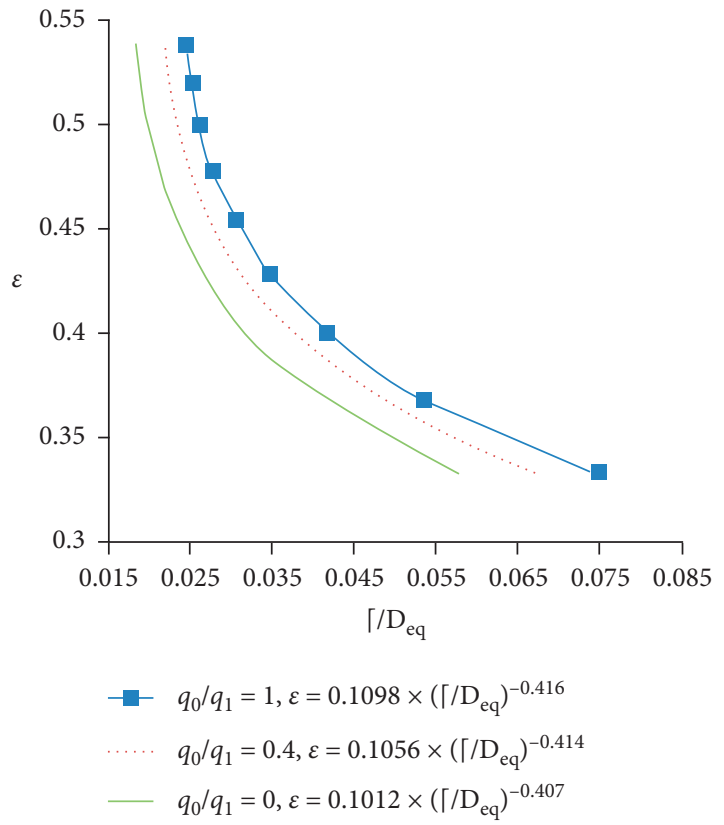

FIGURE 12: Interrelation curve between the dimensionless displacement of the pile head and the embedded ratio of the pile with different values of $q 0 / q_{1}$.

of each antislide pile and elastic modulus of the pile $(E)$. The aforementioned factors should be further considered while attempting to determine the effect of antislide pile construction.

\section{Conclusions}

The Zhangjiawan landslide occurred in Tongjiang County in northeastern Sichuan Province, China. Antislide piles are set in the landslide area in which general features are upper weak and lower hard strata. The site investigation indicated that the maximum displacement of the pile head of the Zhangjiawan landslide was $14.8 \mathrm{~cm}$, with an embedded length of a pile corresponding to $7 \mathrm{~m}$. A reasonably embedded length of the antislide pile in the Zhangjiawan landslide should be $9.03 \mathrm{~m}$ based on the method in the study, which can ensure that the displacement of the pile head does not exceed $10 \mathrm{~cm}$.

An increase in the embedded length of an antislide pile decreases the horizontal displacement of the pile head and its maximum absolute shear force, which is beneficial for landslide stability. However, the bending moment of the pile simultaneously increases, and excessive bending moment increases the amount of bending reinforcement and the cost of the design of an antislide pile. Therefore, the buried depth of the pile should constitute a reasonable length. As an increasing driving force of landslide, the relationship between maximum shear force and maximum bending moment is linear. An increase in the ratio of the driving force between the pile head and slip surface $\left(q 0 / q_{1}\right)$ steadily increases the maximum absolute value of the pile internal forces and displacement of the pile. The relationship between the distribution of the driving force $\left(q 0 / q_{1}\right)$ and the reasonably embedded length of a pile is a quadratic function. Therefore, it is extremely convenient to use the expression to 
calculate the reasonably embedded length for antislide piles to control the horizontal displacement of the pile head in similar engineering applications.

\section{Data Availability}

The displacement data at the head of the antisliding pile are obtained from field surveys and measurements, and basic physical and mechanical parameters of the rock and soil are obtained from laboratory tests.

\section{Conflicts of Interest}

The authors declare that there are no conflicts of interest regarding the publication of this paper.

\section{Acknowledgments}

This research was funded jointly by the Key Research and Development Project of Henan Province (Science and Technology Research Project) (192102310466), Key Projects of Universities in Henan Province (Grant no. 20A570002), and Teaching Reform Project of Henan University Minsheng College (MSJG2017014).

\section{References}

[1] F. Hao, "Study on the stability of push-type landslide on heishan slope of bazhong," Anhui Architecture, vol. 24, no. 3, pp. 179-182, 2017, in Chinese.

[2] N. Zhao and D. M. Yang, "Formation mechanism and prevention measures of landslide in moujiaba village primary School of Tongjiang county," Geological Hazards and Environmental Protection, vol. 26, no. 3, pp. 22-26, 2017, in Chinese.

[3] X. L. Chen, G. Y. Liu, N. Li et al., "Stability evaluation of slope subjected to seismic effect combined with consequent rainfall," Engineering Geology, vol. 266105461 pages, 2020.

[4] J. M. Abbas, Z. H. Chik, and M. R. Taha, "Single pile simulation and analysis subjected to lateral load," Electronic Journal of Geotechnical Engineering, vol. 13, pp. 1-15, 2008.

[5] N. Letizia, C. Iodice, and A. Mandolini, "A local design method for pile foundations," Advances in Civil Engineering, vol. 2018, Article ID 9486945, 6 pages, 2018.

[6] Y. Qiu, Y. H. Lu, C. You et al., "Parameter design of anti-slide pile control method in floor heave," Applied Mechanics and Materials, vol. 170, pp. 541-544, 2012.

[7] D. Rathod, K. Muthukkumaran, and T. G. Sitharam, "Development of non-dimension $\mathrm{p}-\mathrm{y}$ curves for laterally loaded piles in sloping ground," Indian Geotechnical Journal, vol. 47, no. 1, pp. 1-10, 2016.

[8] X. Tang and M. Yang, "Analysis of laterally-loaded piles in weathered rock slopes based on p-y curve method," International Journal of Geotechnical Engineering, pp. 1-11, 2018.

[9] S. Lirer, "Landslide stabilizing piles: experimental evidences and numerical interpretation," Engineering Geology, vol. 149150, pp. 70-77, 2012.

[10] G. Chen, L. Zou, Q. Wang, and G. Zhang, "Pile-spacing calculation of anti-slide pile based on soil arching effect," Advances in Civil Engineering, vol. 2020, Article ID 7149379, 6 pages, 2020.

[11] W. B. Qu and Y. Li, "Appropriate geometry parameters determination of anti-slide pile with stochastic search algorithms," Applied Mechanics and Materials, vol. 170, pp. 819-823, 2012.

[12] C. Li, J. Wu, H. Tang et al., "Model testing of the response of stabilizing piles in landslides with upper hard and lower weak bedrock," Engineering Geology, vol. 204, pp. 65-76, 2016.

[13] G. R. Martin and C.-Y. Chen, "Response of piles due to lateral slope movement," Computers \& Structures, vol. 83, no. 8-9, pp. 588-598, 2005.

[14] R. Frank and P. Pouget, "Experimental pile subjected to long duration thrusts owing to a moving slope," Géotechnique, vol. 58, no. 8, pp. 645-658, 2008.

[15] Y. S. Song, W. Hong, and K. Woo, "Behaviour and analysis of stabilizing piles installed in a cut slope during heavy rainfall," Engineering Geology, vol. 129, 2012.

[16] S. Xiao and R. Wei, "Effects of slip surface inclination on slope pressure exerted on anti-slide piles," ICLEM, vol. 8, pp. 2485-2491, 2010.

[17] H. Tang, X. Hu, C. Xu, C. Li, R. Yong, and L. Wang, "A novel approach for determining landslide pushing force based on landslide-pile interactions," Engineering Geology, vol. 182, pp. 15-24, 2014.

[18] C. Li, Q. Liu, X. Hu et al., "Effect of composite elastic modulus and lateral load pattern on deflection of anti-slide pile head," Journal of Civil Engineering and Management, vol. 22, no. 3, pp. 382-390, 2016.

[19] M. R. Kahyaoğlu, G. İmançl1, G. Özden et al., "Numerical simulations of landslide stabilizing piles: a remediation project in Söke, Turkey," Environmental Earth Sciences, vol. 76, no. 19, p. 656, 2017.

[20] F. S. Tehrani, M. Prezzi, and R. Salgado, "A multidirectional semi-analytical method for analysis of laterally loaded pile groups in multi-layered elastic strata," International Journal for Numerical and Analytical Methods in Geomechanics, vol. 40, no. 12, pp. 15-26, 2016.

[21] J. Xu and L. Ma, "Study on bearing capacity of prestressed pipe pile foundation under horizontal load," The Open Construction and Building Technology Journal, vol. 11, no. 1, pp. 301-312, 2017.

[22] L. Zhang, X. H. Ren, J. X. Zhang et al., "Study on anti-sliding mechanism of slope considering buried depth of anti-sliding pile," Hydropower and Energy Science, vol. 30, no. 4, pp. 73-75, 2012, in Chinese.

[23] W. B. Wei and Y. M. Cheng, "Strength reduction analysis for slope reinforced with one row of piles," Computers and Geotechnics, vol. 36, no. 7, pp. 1176-1185, 2009.

[24] Q. S. Liu and D. F. Liu, "Study on embedded pile length in slope reinforced," Applied Mechanics and Materials, vol. 105, pp. 1497-1504, 2012.

[25] S. Yang, X. Ren, and J. Zhang, "Study on embedded length of piles for slope reinforced with one row of piles," Journal of Rock Mechanics and Geotechnical Engineering, vol. 3, no. 2, pp. 167-178, 2011.

[26] C. Li, X. Wang, H. Tang, G. Lei, J. Yan, and Y. Zhang, “A preliminary study on the location of the stabilizing piles for colluvial landslides with interbedding hard and soft bedrocks," Engineering Geology, vol. 224, pp. 15-28, 2017.

[27] C. Li, J. Yan, J. Wu, G. Lei, L. Wang, and Y. Zhang, "Determination of the embedded length of stabilizing piles in colluvial landslides with upper hard and lower weak bedrock based on the deformation control principle," Bulletin of Engineering Geology and the Environment, vol. 78, no. 2, pp. 1189-1208, 2019.

[28] C.-m. Zhou, W. Shao, K.-l. Yin, and Z.-j. Yang, "Estimating the properties of weathered bedrock and pilerock interaction 
from the geological strength index," Journal of Mountain Science, vol. 15, no. 8, pp. 1757-1776, 2018.

[29] Chinese Railway Publishing House, Second Surveying and Design Institute of the National Department of Chinese Railways, Design and Computation of Anti-slide Piles, Chinese Railway Publishing House, Beijing, China, 1983, in Chinese.

[30] H. Wang, P. Wang, H. Qin et al., "Method to control the deformation of anti-slide piles in zhenzilin landslide," Applied science, vol. 102831 pages, 2020.

[31] C. Zhou, W. Shao, and C. J. van, "Westen comparing two methods to estimate lateral force acting on stabilizing piles for a landslide in the three gorges reservoir, China," Engineering Geology, vol. 173, no. 6, pp. 41-53, 2014.

[32] L. Cong and X. Hu, "Triaxial rheological property of sandstone under low confining pressure," Engineering Geology, vol. 231, pp. 45-55, 2017.

[33] Standardization Administration of China, E41-2005, "Rules for Rock Test of Highway Engineering, Standardization Administration of China, Beijing, China, 2005, in Chinese.

[34] Standardization Administration of China, Standardization Administration of China TB 10025/J127, "Code for Design on Retaining Structures of Railway Subgrade, Standardization Administration of China, Beijing, China, 2006, in Chinese.

[35] W. D. Guo and H. Y. Qin, "Thrust and bending moment of rigid piles subjected to moving soil," Canadian Geotechnical Journal, vol. 47, no. 2, pp. 180-196, 2010.

[36] M. F. Randolph, "The response of flexible piles to lateral loading," Géotechnique, vol. 31, no. 2, pp. 247-259, 1981.

[37] H.-y. Sun, L. N. Y. Wong, Y.-q. Shang, Y.-j. Shen, and Q. Lü, "Evaluation of drainage tunnel effectiveness in landslide control," Landslides, vol. 7, no. 4, pp. 445-454, 2010.

[38] H. G. Poulos, "Design of reinforcing piles to increase slope stability," Canadian Geotechnical Journal, vol. 32, no. 5, pp. 808-818, 1995.

[39] H. Qin and W. Guo, "Response of piles subjected to progressive soil movement," Journal of Geotechnical Engineering, vol. 39, pp. 106-125, 2016.

[40] H. G. Poulos, L. T. Chen, and T. S. Hull, "Model tests on single piles subjected to lateral soil movement," Soils and Foundations, vol. 35, no. 4, pp. 85-92, 1995. 